\title{
Forensics ergonomics in Spain. Research priorities by the Delphi technique
}

\author{
Llaneza Alvarez, F.J. ${ }^{\mathrm{a}{ }^{*} \text {, }}$, Rosal Lopez, $\mathrm{G}^{\mathrm{b}}$, Peña Suarez, Elsa ${ }^{\mathrm{c}}$ and Rodriguez Suarez, $\mathrm{J}^{\mathrm{d}}$ \\ ${ }^{a}$ Ergónomo Forense. Calle Azcarraga, $n^{\circ} 12,2,2^{\circ} \mathrm{D}, 33010$ Oviedo (España) \\ ${ }^{\mathrm{b}}$ Consultor de Ergonomía, Calle Rendueles Llanos , ${ }^{\circ} 8$, entlo, 33205 Gijón (España) \\ ${ }^{\mathrm{C} I n v e s t i g a d o r a ~ F a c u l t a d}$ de Psicología. Universidad de Oviedo. Plaza Feijóo 33003 Oviedo (España), \\ ${ }^{d}$ Profesor Facultad de Psicología. Universidad de Oviedo. Plaza Feijóo 33003 Oviedo (España)
}

\begin{abstract}
Among the many fields of application of Ergonomics, this research deals with the services offered to Justice from the expertise recognized by the Law on prevention of occupational risks within the framework of the Law of Civil Procedure: Ergonomics forensic also called Legal Ergonomics. In Spain there are experiences since 1995 and an important development and this paper is to investigate the actions required for a more widespread use in trials. Consensus methods such as the Delphi survey technique are being employed to help enhance effective decision-making in the future development of Ergonomics Forensics. The Delphi survey is a group facilitation technique, which is an iterative multistage process, designed to transform opinion into group consensus. It is a flexible approach, that is used commonly within the health and social sciences, however, there is little use and practice of ergonomics as a technique to facilitate the participation of all experts involved: judges, lawyers and expert ergonomists
\end{abstract}

Keywords: ergonomics applications, Forensics, Delphi technique, litigation, lawsuits

\section{Introduction}

Among the many fields of application of Ergonomics, this research deals with the services offered to the Judiciary from the expertise recognized by the law on prevention of occupational risks within the framework of the Law of Civil Procedure: Forensic Ergonomics also called Legal Ergonomics.

At the same time, this research tries to verify the development of ergonomics as an occupation and practice as Forensic Assistant for the Administration of Justice, analyzing the existing knowledge in that discipline among the legal actors (attorneys, labour relations and Security Social law consultants and judges), carrying out a proposal for new ways to develop greater awareness and demand for this expertise.

Forensic Ergonomics was initiated in Spain [1] in 1995 and since then its diffusion and practice has grown to the extent that we have now a real know- ledge of this practice and its degree of implementation. The term "Forensic Ergonomics" refers to the application of knowledge in the field of Ergonomics and Applied Psychosociology to legal matters. Specialists in this discipline, or ergonomists are professionals competent to give evidence in judgments about damages to the person within the workplace, or in relation to objects and artifacts in the professional activity. According to the US orientation, "the scientific principles used by forensic practitioners are the very same as those used by HF/E professionals outside forensics; the only real difference is the litigation setting in which they are applied" [2].We believe that the use of leading experts can help you learn about this reality, and the Delphi technique is suitable for this purpose.

Our assumption is that the use of these skills will not only increase the number of lawsuits as a result of the incidence of failure of

\footnotetext{
${ }^{1}$ *Corresponding author: e-mail. fjllanezaa@telecable.es
} 
the preventive arm of the law on occupational accidents and diseases, but also increase the need for more evidentiary basis of disability claims, the liability claims for damage from products and claims for psychosocial risks.

These effects will be noticed despite the lack of information among the legal practitioners (lawyers, social workers and judges), and the lack of training in these skills along with the uncertainty of more scientific and quantitative research methods. ¡This conforms a framework of analysis and some of the assumptions that stem form the hypothesis.

The Delphi technique, mainly developed by Dalkey and Helmer (1963) at the Rand Corporation in the 1950 s, is a widely used and accepted method for achieving convergence of opinion concerning realworld knowledge, ${ }_{2}$ solicited from experts within certain topic areas.

In the literature, Delphi has been applied in various fields such as program planning, needs assessment, policy determination, and resource utilization

\section{Method}

Theoretically, the Delphi process can be continuously iterated until consensus is determined to have been achieved. The literature on Delphi methodology was consulted to derive a cut-off figure for the level of acceptable consensus for the current Delphi study.

For the construction of the questionnaire has been used a Likert scale of 5 points [2] equivalent to 1 being strongly disagree and 5 the symmetrically opposed or strongly agreed with a 3 intermediate point of indifference with the analyzed item. In the preparation of the questionnaire we included control questions (eg, item numbers 10 and 50 ) in order to see the initial stability, as well as experts and questionnaires can be ruled not relevant to the investigation.

\section{Results}

\subsection{Description of the delphi panel}

While we can not talk about an optimal number of experts to participate in a Delphi study, our research will be aimed towards the selection of a heterogeneous group of experts in a number of 25 to 30 people as sufficiently reliable. This panel of experts was set up in our case including individuals from different areas of expertise but related to the object of our investigation. They were finally grouped into three distinct categories: 1- Forensic ergonomists (EF) with experience of more than 3 years and a minimum of 15 trials $(n=14)$, 2- Medical/physicians (MED) who perform assessments and medical physical injury work, legal experts in fields related to Ergonomics Forensic $(n=4)$, and 3Attorneys and Labour relations and Security Social law consultants who routinely resort to the expert ergonomists $(\mathbf{A B})$. The views were collected by email, anonymously and isolated (no one knew who the other experts chosen were). In the first round ${ }_{2}$ questionnaires were distributed and received from 26participants. Second round questionnaires were sent and returned by 21 participants. Between the first and second round of questionnaires there was a reduction of 5 participants from the category of forensic ergonomists (EF).

Responses to the first round of questionnaires were provided by 26 respondents as follows: ergonomic forensics (14) Attorneys (8), doctors (4) In the second round of questionnaires 50 of the initial items were deleted because they had 19 discrimination indices below 0.20 . Items in the second round have values above 0.20 indicating good internal consistency of the questionnaire and a high discrimination power of each item for each person who responds to the scale.

\subsubsection{Negatively valued questions}

The items dealing with contents that express a relevant role of forensic ergonomists and their reports are the least valued by experts, as shown in Table 1. For example participants disagree with the idea that the reports are irrelevant to ergonomic cases of accidents or disagree with the statement that the weight of the report is unimportant or has an unclear influence over the judge's ruling. Comparing scores between the different expert categories highlights the clear disagreement of the lawyers, even more than forensic ergonomists themselves, about the irrelevance of the ergonomic reports to cases of occupational accidents and work injury.

On the other hand, responses highlight a more consistent perception on the part of physicians compared with other specialties, that the language and terms used by forensic ergonomists are poorly understood.

\subsubsection{Positively valued Questions}

Items that show a positive assessment are presented in Table 2. Most of these relate to areas for improvement to be developed within the Forensic Ergonomics as: 
- Increased training of lawyers

- Acceptance of scientific and technical reports

- Improvements in the methodology

- More regulations related to ergonomics.

It is also believed that in the coming years we will see an increase in requests for reports and more expert ergonomists to be appointed. Specifically, the items that show a greater degree of agreement are those indicating that the future of forensic ergonomics lies in specialization of ergonomists- (especially as perceived by doctors in different specialties close to Ergonomics), and those indicating that the report is critical to demonstrate ergonomic contingency in the

case of occupational illness.

By expert category, doctors are in complete agreement with the statement that the field of ergonomics expertise is broader than the judicial expertise in Occupational Health and Safety. We can also -highlight the broad agreement among physicians that the future of Forensic ergonomics lies in the training of lawyers. Attorneys themselves agree with the utility of reports from forensic ergonomists. While ergonomists themselves do not agree to the same extent that other expert categories do with the statement that Forensic Ergonomics will become increasingly sought after by lawyers and social security law consultants.

\subsection{Information collection}

At this stage of the survey the exchange of information with the group of experts takes place. Communication takes place over two days. In the first round, the questionnaire was sent to be completed by the 26 selected experts. We analyzed the information in the questionnaires through the use of computer tools for data analysis SPSS 15.0, proceeding to the tabulation of data and their analysis, which took place after a second mailing of the questionnaire with items individually selected and showing adequate psychometric properties via email. With this feedback is intended that the group know at each stage the results obtained in the preceding stage, thereby seeking to facilitate communication between all members (Vicens, 1985).The information provided in this second batch consisted of mean and frequency distribution of responses in the course of the Likert-type scale of the group.
In the first phase no item showed significant differences between groups at a significance level of 0.05 in the ANOVA comparison of means. In the second phase two differences between the items shown in Table 4 and 5 . Table 4 shows the mean and standard deviation of these items and Table 5 summarizes the results calculated from the mean comparison test ANOVA and Tukey test which specifies between which groups there are differences.

\section{Discussion}

It shows the importance of the Delphi method as a valuable tool for qualitative research to understand the characteristics of Forensic Ergonomics and its development in the coming years.

Another advantage of research with the Delphi technique in the application and development of Forensic Ergonomics, ${ }_{3}$ derives from the multidisciplinary approach of the experts having participated actively in the context of the investigation, as they gain a broader understanding of the topic even increasing their commitment to seeking new ways to disseminate.

The Delphi study results show that most of the different related ergonomics experts agree about Forensic ergonomics utility and the increasingly important role of this expertise. They also agree on the importance of training activities and information dissemination and awareness between the actors of the legal system that should play an active role in relation to the development of forensic ergonomics. Equally significant are new initiatives that will generate greater public legal rules, improving the methodology and the training of ergonomists who intend to pursue this new specialization within the broad field of ergonomics.

\section{References}

[1] Llaneza, J. (2005) La Ergonomía Forense. Ed. Lex Nova

[2] Rudov, M. H., \& Cohen, H. H. (2009). The practice of forensic human factors/ergonomics and related safety professions. Tucson, AZ: Lawyers\& Judges.

[3] Likert, R. (1932). A technique for the Measurement of Attitudes. Archives of Psychology, 140, 44-5

[4] Morales Vallejo, P., Urosa Sanz, B., y Blanco Blanco, A. (2003). Construcción de escalas de actitudes tipo Likert. Madrid: Editorial La Muralla, S.A 
Table 1:

Items or negatively evaluated by experts disagree.

\begin{tabular}{|c|c|c|c|c|c|c|c|c|}
\hline & \multicolumn{2}{|l|}{ EF } & \multicolumn{2}{|c|}{ MED } & \multicolumn{2}{|l|}{$\mathbf{A B}$} & \multicolumn{2}{|l|}{ Total } \\
\hline & M & S.D. & M & S.D. & M & S.D. & M & S.D. \\
\hline 6.The Judges do not usually take into account the ergonomic reports & 2,54 & 1,05 & 3,25 & 1,26 & 3,13 & 1,25 & 2,84 & 1,14 \\
\hline $\begin{array}{l}\text { 10. The ergonomic report is irrelevant to report cases of occupational acci- } \\
\text { dents and work injury. }\end{array}$ & 1,79 & 1,12 & 2,5 & 1,73 & 1,50 & 0,53 & 1,81 & 1,10 \\
\hline $\begin{array}{l}\text { 28.The forensic ergonomists are competent only for reporting occupation- } \\
\text { al diseases and accidents }\end{array}$ & 2,00 & 0,55 & 2,16 & 0,16 & 1,88 & 0,64 & 2,00 & 0,57 \\
\hline $\begin{array}{l}\text { 34.In cases of stress and mobbing is better a psychologist as an ex- } \\
\text { pert forensic ergonomist }\end{array}$ & 3,00 & 1,04 & 2,5 & 0,58 & 3,00 & 1,07 & 2,92 & 0,98 \\
\hline $\begin{array}{l}\text { 36. Forensic ergonomist's fees are one of the reasons that limit their em- } \\
\text { ployment }\end{array}$ & 2,54 & 1,05 & 2,75 & 0,5 & 2,75 & 1,16 & 2,64 & 0,99 \\
\hline $\begin{array}{l}\text { 38. The Ergonomic report does not usually have a clear influence on the } \\
\text { judge's ruling }\end{array}$ & 2,46 & 1,05 & 2 & 0,00 & 2,75 & 0,71 & 2,48 & 0,87 \\
\hline $\begin{array}{l}\text { 42. The language and terms used by forensic ergonomist are } \\
\text { poorly understood }\end{array}$ & 2,86 & 0,77 & 3,25 & 0,96 & 3,00 & 1,07 & 2,96 & 0,87 \\
\hline $\begin{array}{l}\text { 43. The influence of ergonomic report in making decision and award of the } \\
\text { judge is unimportant }\end{array}$ & 2,54 & 1,05 & 2,25 & 0,5 & 2,50 & 0,76 & 2,48 & 0,87 \\
\hline $\begin{array}{l}\text { 46. Labour relations and Security Social law consultants have additional } \\
\text { ergonomics training for attorney and so demand more of this kind of ex- } \\
\text { pertise }\end{array}$ & 2,85 & 0,69 & 3,5 & 0,58 & 2,50 & 1,07 & 2,84 & 0,85 \\
\hline
\end{tabular}

Table 2:

Items valued positively or agreement by the experts.

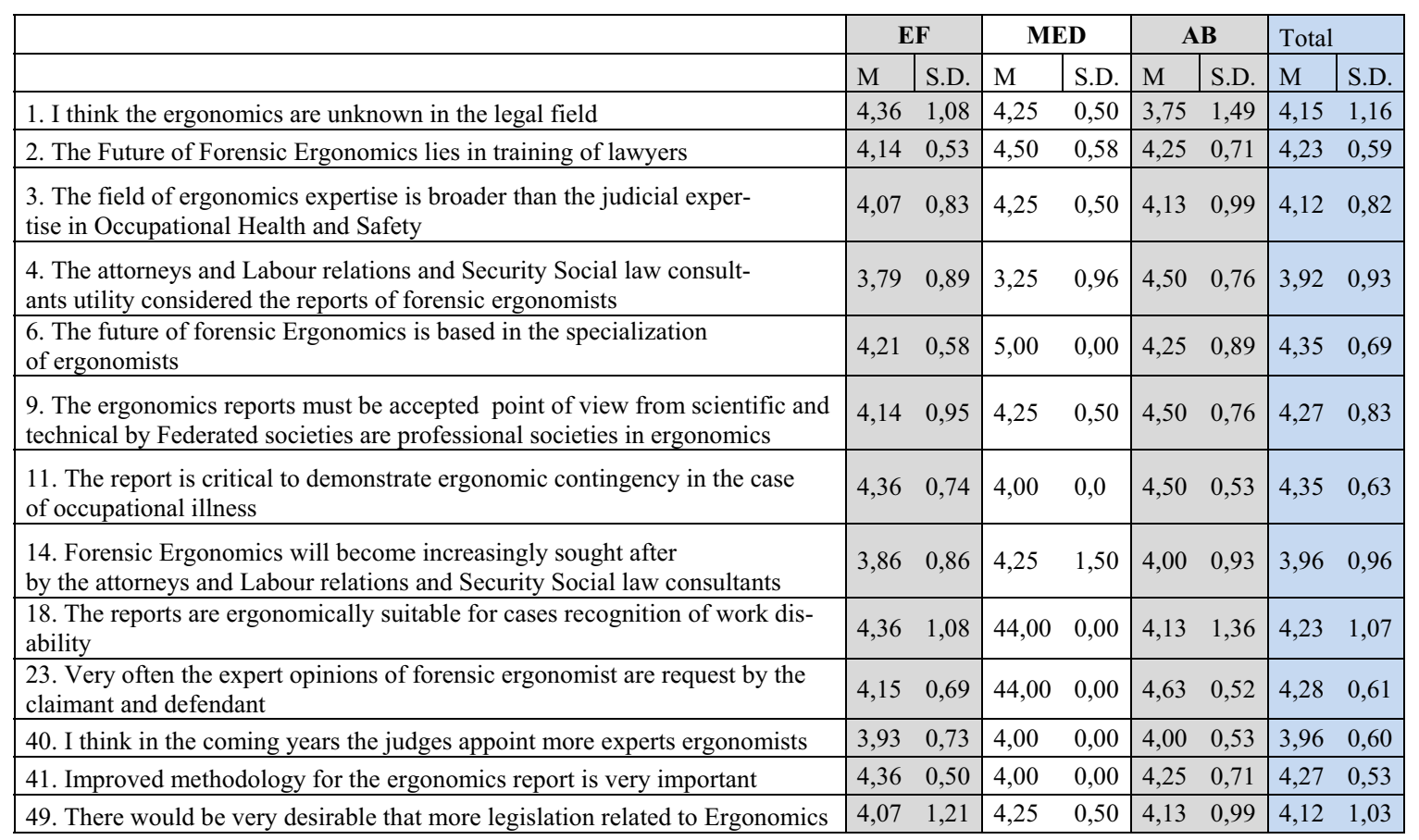


Table 3:

Sample Size by specialty and Delphi phase.

\begin{tabular}{|c|c|c|c|c|c|c|}
\hline Application & & & Frequency & Porcent & Percent valid & Percent cumulative \\
\hline \multirow{4}{*}{$\begin{array}{l}\text { First Round } \\
\text { D1 }\end{array}$} & \multirow[t]{4}{*}{ Valid } & $\mathbf{E F}$ & 14 & 53,8 & 53,8 & 53,8 \\
\hline & & MED & 4 & 15,4 & 15,4 & 69,2 \\
\hline & & ABO & 8 & 30,8 & 30,8 & 100,0 \\
\hline & & Total & 26 & 100,0 & 100,0 & \\
\hline \multirow{4}{*}{\multicolumn{2}{|c|}{$\begin{array}{l}\text { Second } \\
\text { Round } \\
\text { D2 }\end{array}$}} & EF & 10 & 47,6 & 47,6 & 47,6 \\
\hline & & MED & 4 & 19,0 & 19,0 & 66,7 \\
\hline & & $\mathbf{A B O}$ & 7 & 33,3 & 33,3 & 100,0 \\
\hline & & Total & 21 & 100,0 & 100,0 & \\
\hline
\end{tabular}

Table 4:

Descriptive items showing significant differences

\begin{tabular}{|c|c|c|c|c|c|c|}
\hline & \multicolumn{2}{|c|}{ EF } & \multicolumn{2}{|c|}{ MED } & \multicolumn{2}{|c|}{ ABO } \\
\hline & M & S.D. & M & S.D. & M & S.D. \\
\hline $\begin{array}{l}\text { 3. The field of ergonomics expertise is broader than the judicial expertise in Occupational } \\
\text { Health and Safety }\end{array}$ & 4,80 & $\mathbf{0 , 4 2}$ & 4,50 & $\mathbf{1 , 0 0}$ & 3,29 & 1,25 \\
\hline $\begin{array}{llllll}\text { 5.The attorneys and Labour relations and } \begin{array}{c}\text { Security } \\
\text { ants utility considered the reports of forensic ergonomists }\end{array} & \text { Social } & \text { law } & \text { consult- } \\
\end{array}$ & 4,00 & $\mathbf{0 , 0 0}$ & 3,75 & $\mathbf{0 , 5 0}$ & 4,43 & $\mathbf{0 , 5 3}$ \\
\hline 24. Improved methodology for the ergonomics report is very important & 4,60 & $\mathbf{0 , 5 2}$ & 4,25 & $\mathbf{0 , 5 0}$ & 3,71 & 0,49 \\
\hline $\begin{array}{l}\text { 26. The influence of ergonomic report in making decision and award of the judge } \\
\text { is unimportant }\end{array}$ & 3,40 & $\mathbf{0 , 8 4}$ & 2,25 & $\mathbf{0 , 5 0}$ & 2,43 & 0,53 \\
\hline 27. Usually, the different actors present in the courtroom do not know is Ergonomics & 4,10 & 0,74 & $\mathbf{3 , 5 0}$ & 0,58 & 3,14 & 0,38 \\
\hline
\end{tabular}

Table 5:

Results calculated from the mean comparison test ANOVA and Tukey test ${ }^{2}$

\begin{tabular}{|c|c|c|c|c|c|c|c|}
\hline Dependent Variable & $\begin{array}{l}\text { (I) cat- } \\
\text { prof3 }\end{array}$ & $\begin{array}{c}(\mathrm{J}) \\
\text { cat- } \\
\text { prof3 }\end{array}$ & Mean Differ (I-J) & Standar Error & Sig. & \multicolumn{2}{|c|}{ IC $95 \%$} \\
\hline & & & & & & L.S & L.I \\
\hline \multirow[t]{6}{*}{$\begin{array}{l}3 . \text { The field } \\
\text { of ergonomics expertise is } \\
\text { broader than the judicial exper- } \\
\text { tise in Occupational Health and } \\
\text { Safety }\end{array}$} & $\mathrm{EF}$ & MED & ,30000 & ,52228 & ,835 & $-1,0329$ & 1,6329 \\
\hline & & $\mathrm{ABO}$ & $1,51429(*)$ & ,43506 &, 007 & ,4039 & 2,6246 \\
\hline & MED & $\mathrm{EF}$ &,- 30000 & ,52228 &, 835 & $-1,6329$ & 1,0329 \\
\hline & & $\mathrm{ABO}$ & 1,21429 & ,55333 & ,099 &,- 1979 & 2,6265 \\
\hline & $\mathrm{ABO}$ & EF & $-1,51429(*)$ & ,43506 & ,007 & $-2,6246$ &,- 4039 \\
\hline & & MED & $-1,21429$ &, 55333 & ,099 & $-2,6265$ & ,1979 \\
\hline $\begin{array}{l}5 . \text { The attorneys and Labour } \\
\text { relations and Security Social } \\
\text { law consult- } \\
\text { ants utility considered the re- } \\
\text { ports of forensic ergonomists }\end{array}$ & $\overline{E F}$ & MED & ,25000 & ,21890 &, 502 &,- 3087 &, 8087 \\
\hline
\end{tabular}

In round I no item showed significant differences between groups. In phase two there are differences between these items 


\begin{tabular}{|c|c|c|c|c|c|c|c|}
\hline & & $\mathrm{ABO}$ &,- 42857 & , 18234 &, 074 &,- 8939 &, 0368 \\
\hline & MED & $\mathrm{EF}$ &,- 25000 & ,21890 & ,502 &,- 8087 &, 3087 \\
\hline & & $\mathrm{ABO}$ &,$- 67857\left(^{*}\right)$ & ,23191 &, 023 & $-1,2705$ &,- 0867 \\
\hline & $\mathrm{ABO}$ & $\mathrm{EF}$ &, 42857 &, 18234 &, 074 &,- 0368 & ,8939 \\
\hline & & MED & ,67857(*) & 23191 & ,023 &, 0867 & 1,2705 \\
\hline \multirow[t]{6}{*}{$\begin{array}{l}24 . \quad \text { Improved methodology } \\
\text { for the ergonomics report is } \\
\text { very important }\end{array}$} & $\mathrm{EF}$ & MED & ,35000 & ,29838 & ,484 &,- 4115 & 1,1115 \\
\hline & & $\mathrm{ABO}$ & ,88571(*) &, 24854 & ,006 &, 2514 & 1,5200 \\
\hline & MED & $\mathrm{EF}$ &,- 35000 & ,29838 & ,484 & $-1,1115$ & ,4115 \\
\hline & & $\mathrm{ABO}$ &, 53571 & ,31612 & ,234 &,- 2711 & 1,3425 \\
\hline & $\mathrm{ABO}$ & $\mathrm{EF}$ &,$- 88571\left(^{*}\right)$ & ,24854 & ,006 & $-1,5200$ &,- 2514 \\
\hline & & MED &,- 53571 & ,31612 & ,234 & $-1,3425$ &, 2711 \\
\hline \multirow[t]{6}{*}{$\begin{array}{l}26 . \text { The influence } \\
\text { of ergonomic report in mak- } \\
\text { ing decision and award of the } \\
\text { judge is unimportant }\end{array}$} & $\mathrm{EF}$ & MED & $1,15000(*)$ & ,41516 & ,032 & ,0904 & 2,2096 \\
\hline & & $\mathrm{ABO}$ & ,97143(*) & ,34583 &, 030 & ,0888 & 1,8540 \\
\hline & MED & $\mathrm{EF}$ & $-1,15000(*)$ & ,41516 & ,032 & $-2,2096$ &,- 0904 \\
\hline & & $\mathrm{ABO}$ &,- 17857 & ,43985 & ,914 & $-1,3011$ & ,9440 \\
\hline & $\mathrm{ABO}$ & EF &,$- 97143\left(^{*}\right)$ & ,34583 &, 030 & $-1,8540$ &,- 0888 \\
\hline & & MED &, 17857 & ,43985 & ,914 &,- 9440 & 1,3011 \\
\hline \multirow[t]{6}{*}{$\begin{array}{l}\text { 27. Usually, the different actors } \\
\text { present in the courtroom do not } \\
\text { know is Ergonomics }\end{array}$} & $\mathrm{EF}$ & MED & 60000 & ,36248 & ,249 &,- 3251 & 1,5251 \\
\hline & & $\mathrm{ABO}$ &, $95714(*)$ & ,30194 &, 014 &, 1865 & 1,7277 \\
\hline & MED & $\mathrm{EF}$ &,- 60000 & ,36248 & ,249 & $-1,5251$ &, 3251 \\
\hline & & $\mathrm{ABO}$ &, 35714 & ,38403 & ,629 &,- 6230 & 1,3372 \\
\hline & $\mathrm{ABO}$ & $\mathrm{EF}$ &,$- 95714(*)$ & ,30194 & ,014 & $-1,7277$ &,- 1865 \\
\hline & & MED &,- 35714 & ,38403 & ,629 & $-1,3372$ &, 6230 \\
\hline
\end{tabular}

Table 6:

Descriptive between the two phases of the Delphi panel ${ }^{3}$.

\begin{tabular}{|c|c|c|c|c|}
\hline & & apl & M & S.D. \\
\hline \multirow{2}{*}{\multicolumn{2}{|c|}{ 1. I think the ergonomics are unknown in the legal field }} & D1 & 4,15 & 1,16 \\
\hline & & D2 & 4,00 & 0,95 \\
\hline \multirow{2}{*}{\multicolumn{2}{|c|}{ 2. The Future of Forensic Ergonomics lies in training of lawyers }} & D1 & 4,23 & 0,59 \\
\hline & & D2 & 3,86 & 0,48 \\
\hline \multirow{2}{*}{\multicolumn{2}{|c|}{$\begin{array}{l}\text { 3. The field of ergonomics expertise is broader than the judicial expertise in Occupational } \\
\text { Health and Safety }\end{array}$}} & D1 & 4,12 & 0,82 \\
\hline & & D2 & 4,24 & 1,09 \\
\hline \multirow{2}{*}{\multicolumn{2}{|c|}{$\begin{array}{l}\text { 4. The ergonomic report is irrelevant to report cases of occupational accidents and work in- } \\
\text { jury. }\end{array}$}} & D1 & 1,81 & 1,10 \\
\hline & & D2 & 2,05 & 0,86 \\
\hline \multirow{2}{*}{\multicolumn{2}{|c|}{$\begin{array}{l}\text { 5. The attorneys and Labour relations and Security } \\
\text { ants utility considered the reports of forensic ergonomists }\end{array}$}} & D1 & 3,92 & 0,93 \\
\hline & & D2 & 4,10 & 0,44 \\
\hline
\end{tabular}




\begin{tabular}{|c|c|c|c|c|}
\hline \multirow[t]{2}{*}{6.} & \multirow[t]{2}{*}{ The Judges do not usually take into account the ergonomic reports } & D1 & 2,84 & 1,14 \\
\hline & & D2 & 3,10 & 0,94 \\
\hline & \multirow[t]{2}{*}{ The future of forensic Ergonomics is based in the specialization of ergonomists } & D1 & 4,35 & 0,69 \\
\hline & & D2 & 3,90 & 0,89 \\
\hline & \multirow[t]{2}{*}{$\begin{array}{l}\text { The ergonomics reports must be accepted point of view from scientific and technical by } \\
\text { Federated societies are professional societies in ergonomics }\end{array}$} & D1 & 4,27 & 0,83 \\
\hline & & D2 & 3,86 & 0,96 \\
\hline & \multirow[t]{2}{*}{$\begin{array}{l}\text { The report is critical to demonstrate ergonomic contingency in the case } \\
\text { of occupational illness }\end{array}$} & D1 & 4,35 & 0,63 \\
\hline & & D2 & 4,43 & 0,60 \\
\hline & \multirow[t]{2}{*}{$\begin{array}{l}\text { Forensic Ergonomics will become increasingly sought after by the attorneys and Labour } \\
\text { relations and Security Social law consultants }\end{array}$} & D1 & 3,96 & 0,96 \\
\hline & & D2 & 4,29 & 0,56 \\
\hline & \multirow[t]{2}{*}{ The most important role of the forensic ergonomist is his intervention in the courtroom } & D1 & 3,00 & 1,29 \\
\hline & & D2 & 3,57 & 1,03 \\
\hline & \multirow[t]{2}{*}{ The reports are ergonomically suitable for cases recognition of work disability } & D1 & 4,23 & 1,07 \\
\hline & & D2 & 4,43 & 0,75 \\
\hline & \multirow[t]{2}{*}{$\begin{array}{l}\text { Very often the expert opinions of forensic ergonomist are request by the claimant and de- } \\
\text { fendant. }\end{array}$} & D1 & 4,28 & 0,61 \\
\hline & & D2 & 4,19 & 1,03 \\
\hline & \multirow[t]{2}{*}{$\begin{array}{l}\text { The best way to spread the skills of the ergonomist is through relationships with the attor- } \\
\text { ney }\end{array}$} & D1 & 3,85 & 0,78 \\
\hline & & D2 & 4,10 & 0,70 \\
\hline & \multirow[t]{2}{*}{$\begin{array}{l}\text { To act as forensic ergonomist has to be a university degree and higher technical risk pre- } \\
\text { vention }\end{array}$} & D1 & 3,65 & 1,06 \\
\hline & & D2 & 4,14 & 0,73 \\
\hline & \multirow[t]{2}{*}{ In cases of stress and mobbing is better a psychologist as an expert forensic ergonomist } & D1 & 2,92 & 0,98 \\
\hline & & D2 & 3,05 & 0,74 \\
\hline \multirow{2}{*}{\multicolumn{2}{|c|}{ 17. The lawyers who turn first to a forensic ergonomics are satisfied with his testimony }} & D1 & 3,92 & 0,76 \\
\hline & & D2 & 4,14 & 0,73 \\
\hline & \multirow[t]{2}{*}{ Forensic ergonomist's fees are one of the reasons that limit their employment } & D1 & 2,64 & 0,99 \\
\hline & & D2 & 2,38 & 1,07 \\
\hline \multirow{2}{*}{\multicolumn{2}{|c|}{ 19. Only large law firms can afford to request an ergonomic expertise }} & D1 & 2,28 & 1,10 \\
\hline & & D2 & 2,43 & 0,93 \\
\hline \multirow{2}{*}{\multicolumn{2}{|c|}{ 20. The ergonomics report does not usually have a clear influence on the judge's ruling }} & D1 & 2,48 & 0,87 \\
\hline & & D2 & 2,71 & 1,10 \\
\hline 21. & $\begin{array}{l}\text { Typically, the forensic ergonomist before moving on to defend his report should explain } \\
\text { that court } \\
\text { room }\end{array}$ & D1 & 3,77 & 0,99 \\
\hline & & D2 & 3,81 & 0,68 \\
\hline & I think in the coming years the judges appoint more experts ergonomists & D1 & 3,96 & 0,60 \\
\hline & & D2 & 3,57 & 0,93 \\
\hline & In cases of work accidents the ergonomics report is not very relevant & D1 & 2,04 & 1,11 \\
\hline & & D2 & 2,19 & 1,03 \\
\hline & Improved methodology for the ergonomics report is very important & D1 & 4,27 & 0,53 \\
\hline & & D2 & 4,24 & 0,62 \\
\hline & The language and terms used by forensic ergonomist are poorly understood & D1 & 2,96 & 0,87 \\
\hline
\end{tabular}




\begin{tabular}{|c|c|c|c|}
\hline & $\mathrm{D} 2$ & 2,76 & 0,77 \\
\hline \multirow[t]{2}{*}{$\begin{array}{l}\text { 26. The influence of ergonomic report in making decision and award of the judge } \\
\text { is unimportant }\end{array}$} & D1 & 2,48 & 0,87 \\
\hline & D2 & 2,86 & 0,85 \\
\hline \multirow[t]{2}{*}{ 27. Usually, the different actors present in the courtroom do not know is Ergonomics } & D1 & 3,76 & 1,05 \\
\hline & D2 & 3,67 & 0,73 \\
\hline \multirow[t]{2}{*}{ 28. Forensic Ergonomics is more advanced in Asturias than in other regions of Spain } & D1 & 3,80 & 0,91 \\
\hline & $\mathrm{D} 2$ & 3,52 & 0,98 \\
\hline \multirow[t]{2}{*}{$\begin{array}{l}\text { 29. Labour relations and Security Social law consultants have additional ergonom- } \\
\text { ics training for attorney and so demand more of this kind of expertise }\end{array}$} & D1 & 2,84 & 0,85 \\
\hline & D2 & 3,05 & 0,74 \\
\hline \multirow[t]{2}{*}{ 30. The reports should be more quantitative ergonomic and more decisive conclusions } & D1 & 3,77 & 0,76 \\
\hline & D2 & 3,76 & 0,94 \\
\hline \multirow[t]{2}{*}{ 31. There would be very desirable that more legislation related to Ergonomics } & D1 & 4,12 & 1,03 \\
\hline & D2 & 3,86 & 1,11 \\
\hline
\end{tabular}

Comparing the phases in each professional category there are no differences except in the group of doctors, table 7 which show significant differences between the phases in two items: the number 7 and 11

Table 7:

Descriptive between the two phases of the Delphi panel for specialty Doctors

\begin{tabular}{|ll|r|r|}
\hline & Application & Media & \multicolumn{1}{c|}{$\begin{array}{c}\text { Standar } \\
\text { Desviation }\end{array}$} \\
\hline $\begin{array}{l}\text { 7. The future of forensic Ergonomics is based in the } \\
\text { specialization of ergonomists }\end{array}$ & D 2 & 5,0000 &, 00000 \\
& D 2 & 1,0000 &, 81650 \\
$\begin{array}{l}\text { 11. Lo más importante del papel del perito es su } \\
\text { intervención en la sala }\end{array}$ & 3,5000 &, 50000 \\
& & 3,5000 & 1,00000 \\
\hline
\end{tabular}

